\section{Auditory differential conditioning of the rabbit nictitating membrane response: III. Effects of US shock intensity and duration'}

ALAN B. ASHTON, STEPHEN C. $B I T G O O D, 2$ and JOHN W. MOORE, University of Massachusetts, Amherst, Mass. 01002

Forty-eight rabbits were employed to investigate effects of US intensity and US duration upon differential conditioning of the nictitating membrane response. It was found that the level of conditioning varied directly with increases in intensity and duration, while differential performance was influenced only by intensity. Results were attributed to the increasing noxious ness of the US and were discussed with reference to studies of human eyelid conditioning.

According to Spence's (1958) treatment of classical defensive conditioning, an increase in the intensity of the unconditioned stimulus (US) results in an increase of generalized drive, $\mathrm{D}$, which, when combined multiplicatively with habit strength, $H$, results in a higher level of responding. Later studies by Spence and his associates suggested that US intensity also contributes to $H$ directly by way of some unspecified mechanism. In the case of human eyelid conditioning, there is evidence to suggest that the habit component of the US derives, at least partially, from drive reduction accompanying an attenuation or termination of the noxious US. The drive reduction hypothesis predicts that an increase in US duration results in delay of reinforcement with respect to the $C R$ and hence a slower rate of conditioning. Numerous studies of human eyelid conditioning have illustrated the direct relationship between $C R$ performance and US intensity (e.g., Spence \& Platt, 1966). A smaller number of studies have indicated poorer conditioning with a long (1000 msec) airpuff US compared with one of shorter duration $(50 \mathrm{msec})$, thereby supporting the drive reduction viewpoint (Runquist \& Spence, 1959; Meiselman \& Moore, 1965;Dufort, 1967).

In the case of differential conditioning, Spence's (1958) theory predicts faster conditioning and better differentiation as US intensity is increased, and this prediction has been substantiated in two human eyelid conditioning studies carried out in his laboratory (Runquist, Spence, \& Stubbs,
1958; Spence \& Tandler, 1963). There have been no reports of the effects of US duration or of the possible interaction of US intensity and duration in differential conditioning. The present experiment sought to investigate these variables using the rabbit nictitating membrane response conditioned by electric shock to the region of the eye. \section{SUBJECTS}

Subjects in the present investigation were 48 naive male and female New Zealand White rabbits, $90-120$ days old at the outset of the experiment. All Ss were individually housed and maintained on ad lib food and water.

\section{APPARATUS}

A detailed description of the apparatus and technique for recording from the nictitating membrane has been provided in a previous report (O'Malley, Hupka, \& Moore, 1969).

\section{PROCEDURE}

Rabbits were randomly assigned to one cell of a 2 by 3 factorial design combining US durations of 50 and $350 \mathrm{msec}$ and US intensities of .5-, 2-, and 4-mA ac shock. It was feared that a US duration longer than $350 \mathrm{msec}$ would produce poor conditioning through overarousal, particularly at the highest value of shock intensity. The shock USs were delivered to $S$ via the wound clips attached near the right eye. Five sessions of differential conditioning were given, each session consisting of 100 trials with an average in tertrial interval of $60 \sec (50-, 60$-, and 70-sec intervals). A 400-Hz tone served as the $\mathrm{CS}+$ for all $\mathrm{Ss}$, while a $1000-\mathrm{Hz}$ tone was the $\mathrm{CS}-$. CSt and $\mathrm{CS}-$ trials were randomly presented but equated in blocks of 20 trials for purposes of analysis. The interstimulus in terval was $630 \mathrm{msec}$, and the CS+ terminated with the US. CS- was maintained for like durations. A conditioned response (CR) was defined as a positive deflection of the recording pen greater than $1 \mathrm{~mm}$ within the CS-US interval.

\section{RESULTS AND DISCUSSION}

Figure 1 depicts differential performance as a function of intensity and duration. An analysis of variance of per cent CRs for the five conditioning sessions yielded significant main effects of US intensity $[F(2,36)=18.76, p<.001]$ and duration $[F(1,36)=4.44, p<.05]$, indicating that responding bore a positive relation to increments of both variables. In addition to the main effects, a significant Intensity by Differentiation interaction $[\mathrm{F}(2,36)=4.97$, $\mathrm{p}<.025]$ indicated that differential performance improved with increases in US intensity. A failure to obtain significant interaction between US duration and other variables suggests that US intensity but not duration affected differentiation in the present experiment. Figure 1 further suggests that the downturn of responding to CS- did not occur until asymptotic performance was achieved to CSt. It seems likely, therefore, that a downturn of responding to $\mathrm{CS}$ - was absent in the $.5-\mathrm{mA}$ intensity groups because the CSt curves were still climbing by the end of training.

The effects of US intensity observed in the present experiment using the nictitating membrane response of the rabbit are

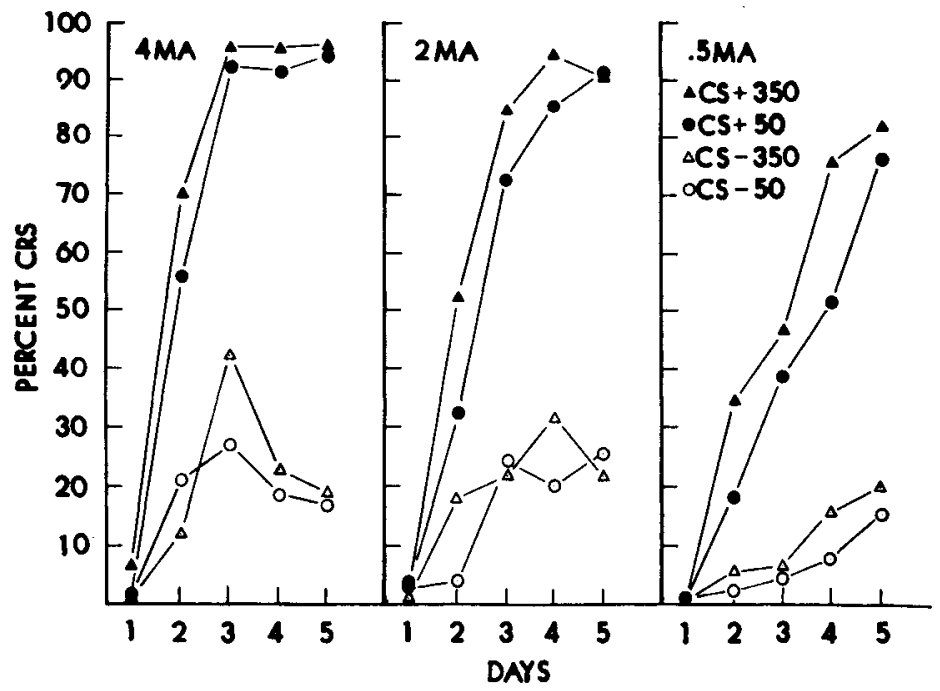

Fig. 1. Acquisition and differential responding for combinations of US intensity and US duration as a function of days. 
consistent with data from human differential ey elid conditioning in that increases in US intensity led to faster acquisition and differentiation. The observed facilitory effect of US duration, however, stands in opposition to data from simple human eyelid conditioning. The discrepancy might be reconciled by assuming that the nictitating membrane response does little to reduce the noxiousness of a shock US delivered to the region of the eye. This being the case, there would be little basis for treating the $\mathrm{CR}$ as being under instrumental control. With such instrumental control ruled out, it would be gratuitous to suppose that a delay of reinforcement operated in this situation. Nevertheless, it should be emphasized that the values of US duration employed with human Ss have been more extreme (e.g., 50 vs $1000 \mathrm{msec}$ ) than those employed in the present study, and this might account for the apparent discrepancy between the two preparations. Thus, a 350-msec airpuff might facilitate human eyelid conditioning compared with a US of shorter duration. Similarly, an electric shock US of $1000 \mathrm{msec}$ could conceivably interfere with conditioning compared with shocks of shorter duration.

\section{REFERENCES}

DUFORT, R. H. Eyelid conditioning as a function of UCS duration with drive equated. Journal of Experimental Psychology, 1967, 74, 321-323. GORMEZANO, 1. Classical conditioning. In J. B. Sidowski (Ed.), Experimental methods and instrumentation in psychology. New York: McGraw-Hill, 1966.

MEISELMAN, H. L., \& MOORE, J.W. The effects of percentage reinforcement, UCS duration, and experience with procedure on the conditioned eyelid response. Psychonomic Science, 1965, 3, 335-336.

O'MALLEY, P., HUPKA, R. B., \& MOORE, J. W Auditory differential conditioning of the rabbit nictitating membrane response: I. Effects of mixed- and separate-phase training. Psychonomic Science, 1969, 15, 123-124.

RUNQUIST, W. N., \& SPENCE, K. W. Performance in eyelid conditioning as a function of UCS duration. Journal of Experimental Psy chology, 1959, 57, 249-252.

RUNQUIST, W. N., SPENCE, K. W., \& STUBBS, D. W. Differential conditioning and intensity of the UCS. Journal of Experimental Psy chology, $1958,55,51-55$.

SPENCE, K. W. A theory of emotionally based drive (D) and its relation to performance in simple learning situations. American Psychologist, 1958, 13, 131-141.

SPENCE, K.W., \& PIATT, J. R. UCS in tensity and performance in eyelid conditioning. Psychological Bulle tin, 1966, 65, 1-10.

SPENCE, K. W., \& TANDLER, B. F. Differential eyelid conditioning under equated drive as a function of the reinforcing UCS. Journal of Experimental Psy chology, 1963, 65, 35-38. NOTES

1. This research was supported in part by NSF Grant BG-5480.

2. Now at the University of lowa.
New Zealand White rabbits, 90-120 days old.

\section{Apparatus}

A detailed description of the apparatus and technique for recording from the nictitating membrane has been provided in a previous report (O’Malley, Hupka, \& Moore, 1969).

\section{Procedure}

Two groups of $16 \mathrm{Ss}$ received 5 days of conventional differential conditioning (i.e., the reinforced and nonreinforced CSs were presented equally often in a random sequence) for 120 trials/day with an average intertrial interval (ITI) of $60 \mathrm{sec}$ and CS-UCS interval of $250 \mathrm{msec}$. Tones of 1700 and $300 \mathrm{~Hz}$ were used as the reinforced and nonreinforced CSs. The CSs were tone onset for one group and tone off set for the other. An intertrial tone occupied the en tire ITI. A conditioned response (CR) was defined as any $1-\mathrm{mm}$ positive deflection of the recording pen within the interstimulus interval. The UCS consisted of a $2-\mathrm{mA}$ ac shock of $50-\mathrm{msec}$ duration applied to wound-clip electrodes on the infra-orbital region of the right eye.

\section{Results and Discussion}

Figure 1 shows that good differentiation was obtained with both the tone onset and offset procedures $(F=208.41$, df $=1 / 28$, $\mathrm{p}<.001$ ). The slightly better differentiation in the tone onset group, evident in the figure, was not statistically significant. Nevertheless, these data are quite comparable with those obtained with humans.

\section{EXPERIMENT 2}

The purpose of this experiment was to determine the effect of a single intertrial (ITI) tone upon differentiation to two other tones. Experiments in human eyelid conditioning have shown that the presence of a constant intertrial tone can enhance differential conditioning to tonal CSs compared with control groups which hear only white noise during the ITI (Moore \& Newman, 1966). This result has been interpreted in terms of an accrual of inhibition to the intertrial tone and resulting positive induction effect which elevates responding to $\mathrm{CS}+$. The contrast is enhanced further by a concomitant depression in responding to $\mathrm{CS}-$ which can be attributed to the generalization of intertrial inhibition. Alternatively, the intertrial tone seems to provide an anchoring stimulus which heightens the discriminability between CS+ and $\mathrm{CS}-$ at a perceptual level.

Four groups of eight $S$ s received a sequence of $60 \mathrm{CS}+, 10 \mathrm{CS}-, 20 \mathrm{CS}+$, $10 \mathrm{CS}-$, and 20 differential trials (i.e., CS+ and $\mathrm{CS}$ - were presented equally often in a random sequence) on Day 1 . Ss were given $120 \mathrm{trials} /$ day of conventional differential conditioning on Days 2 and 3. Each group formed one combination of a 2 by 2 factorial design. One dimension of the or absence of a $1000-\mathrm{Hz}$ tone during the ITI with frequency separations $(\Delta f)$ between

\section{EXPERIMENT 1} Subjects

The Ss were 32 naive male and female 